\title{
Students Perception of Mobile Learning during COVID-19 in Bangladesh: University Student Perspective
}

\author{
Bikram Biswas ${ }^{1 *}$, Sajib Kumar Roy ${ }^{2}$, Falguni Roy ${ }^{1}$
}

\begin{abstract}
${ }^{1}$ Noakhali Science and Technology University, Noakhali-3814, BANGLADESH
${ }^{2}$ Hajee Mohammad Danesh Science and Technology University, Dinaipur-5200, BANGLADESH

*Corresponding Author: bikramju1020@gmail.com
\end{abstract}

Citation: Biswas, B., Roy, S. K., \& Roy, F. (2020). Students Perception of Mobile Learning during COVID-19 in Bangladesh: University Student Perspective. Aquademia, 4(2), ep20023. https://doi.org/10.29333/aquademia/8443

\begin{tabular}{|c|c|}
\hline ARTICLE INFO & ABSTRACT \\
\hline Received: 13 Jun. 2020 & The aim of this study is to measures the student's perception of using mobile for learning during COVID-19 in \\
\hline Accepted: 16 Jul. 2020 & $\begin{array}{l}\text { Bangladesh especially at the university student's perspective. During the COVID-19 pandemic period, mobile } \\
\text { learning may help the students to fulfill the study gap. Due to COVID-19 pandemic } 213 \text { countries, higher } \\
\text { education has affected all over the world of June } 2020 \text {. Although all of the developed countries considered mobile } \\
\text { learning as an effective tool for education, it is not used properly in Bangladesh. This survey method conducted } \\
\text { on } 416 \text { students from different university students in Bangladesh to understand the student's perception of using } \\
\text { mobile phones as a learning system. The findings of this study show that most of the students at the university } \\
\text { level have a positive perception of m-learning. This study revealed that m-learning is very helpful to recover the } \\
\text { study gap during this COVID- } 19 \text { pandemic time and the findings of this study will help the education policymaker } \\
\text { as well as the educational institutions to incorporate mobile learning technology for the whole system where } \\
\text { social media may enhance the process of teaching and learning. }\end{array}$ \\
\hline
\end{tabular}

Keywords: mobile learning, students' perceptions, COVID-19, Bangladesh

\section{INTRODUCTION}

Nowadays, Mobile learning (m-learning) has become a popular learning system for education especially higher education all over the world because of its multi-functionality characteristic and effectiveness. Bangladesh is one of the fastest countries of mobile spreading in the world has around 8 million smartphone users which ranked out of the 50 countries in the world (Ash, 2019). Bangladesh already initiated a project on National ICT policy-2009 to make the country as a middle-income nation in the year 2021 by emphasizing the application of ICT based education from primary to tertiary level will help to accomplish the goal ("Digital Bangladesh: dreams and reality", 2015). Under the ICT policy-2009, the government had provided laptops and multi-media projectors around 20,000 institutions in Bangladesh within 2014 (Chandan, 2015). Also, the government has taken the initiative to provide free Wi-Fi connection to all of the public universities. On the other side, the total number of Mobile Phone subscribers had reached 159.780 Million at the end of March 2019 (BTRC, 2019). Most of the students at the tertiary level have a smartphone which they can easily use for their academic purpose both offline and online. M-learning reflects remote teaching tactics for teachers as well as learning strategies for students at the university level because it helps to learn anytime from anywhere. It also may help the students to reduce the study gap that could play an alternative learning methodology during COVID-19 (Naciri et al., 2020). After declaring COVID19 as pandemic disease, many countries including Bangladesh have taken initiative to close their educational institutions to reduce the effect of the virus (World Health Organization, 2020b). Bangladesh had closed all of the educational institutions from the 18th of March, 2020 which became a cause of affecting the quality of education and also the student's future life (Usak et al., 2020). So for overcoming this situation, an innovative learning methodology becomes very important nowadays (Toquero, 2020) and M-learning could play a vital role for the mobile devices uses in the educational sector (Sönmez, Göçmez, Uygun, Ataizi, \& Learning, 2018, Aubusson, Schuck, \& Burden, 2009).

For the COVID-19 pandemic time, the education system of the world has affected extremely. Many countries of the world have closed their educational institutions to reduce the spread of this virus which become the cause of many challenges (Naciri et al., 2020). The scenario is not different for Bangladesh. Every educational institution of Bangladesh including the higher educational institutions remains closed from 18 March 2020. So, for optimizing the effects of the 
pandemic in the education sector, the University Grant Commission (UGC) has opted for online teaching to all the universities. And, some teachers have already started to participate in the online classes to reduce the study gap of the students. At this stage, m-learning might be a helpful tool for both the students and teachers. Before claiming that " $\mathrm{m}$ learning is a helpful tool for learning”, we should know about the perception of mobile learning of students during this pandemic situation. This novel study focuses on the perception of students' mobile learning during this pandemic situation. This study comes up with various literature on mobile learning in numerous respects. As a developing country, like Bangladesh where the majority belongs to the youth age group, there have a few studies of using mobile phones among university students' perception of their studies. This study aims to look at the students' perception of using mobile phones in informal education. Many researchers found that mobile learning always supports teaching and learning. Although many developed countries used to m-learn as an effective tool for education (Fuegen, 2012), there is a lack of studies that focus on examining students' perceptions of mobile learning, particularly in the context of Bangladesh. Education for all is now a common concern most of the developing countries including Bangladesh. The governments of Bangladesh are spending and investing a lot of money to develop the use of ICTs at all levels of educational institutions. As mobile devices would be a potential tool for education at the higher studies in Bangladesh so it has now become important and essential to measures the perception of students using mobile phones as a learning tool during this pandemic time.

The main objective of the research is to know the student's perception of using mobile phones as a learning tool during COVID-19 time and also the perception of mobile learning to recover the study gap at this pandemic time and the process of improving their academic performance by utilizing mobile learning.

\section{LITERATURE REVIEW}

The mobile device is now a common device which used at all aspect of life both developed and developing countries. Mobile learning helps us to provide the enhancement of teaching and learning capability (Al-Hunaiyyan et al., 2017). It has many advantages. The method of teaching can occur at any place, anytime and anywhere and the process of learning is not limited to a specific place (Corbeil \& Valdes-Corbeil, 2007). It assists the students to improve technological skills, to help of sharing knowledge, and also develop their learning capability (AlEmran, Elsherif, \& Shaalan, 2016).

"M-learning is also providing us with an opportunity that is to change the existing learning strategies to give students a much flexible approach to managing their learning experiences" (Al-Hunaiyyan et al., 2018). Quinn (2000) defined m-learning is a new learning technique by using mobile devices. Furthermore, Kinash et al. (2012) defined m-learning is useful for educational purposes by using mobile devices. Mobile learning plays a significant role in education in both teaching and learning (Klassen et al., 2013). There has a difference between e-learning and m-learning. Usually, Elearning is the process of learning without participating in the classroom (Rosenberg, 2001). Sharples (2005) illustrate mlearning is the extension of e-learning (Sharples, 2005). Winters (2006) also concludes that m-learning is a division of e-learning. M-learning can be defined as "the acquisition of any knowledge and skills through the use of mobile technology, anywhere, and anytime" (Hashemi, Azizinezhad, Najafi, \& Nesari, 2011, p. 1).

Ozdamli and Cavus (2011) had mentioned a few characteristics of mobile learning such as ubiquitous, portable, blended, private, interactive, collaborative, and instant (Ozdamli \& Cavus, 2011). Mobile learning considers as portable because a learner can use it anytime, anywhere (Cavus \& Ibrahim, 2009). It is ubiquitous because it changes the classroom pattern from the traditional classroom to anytime and anywhere education (Cavus \& Ibrahim, 2009; Kukulska Hulme et al., 2009). Mobile learning is also "blended as the teachers and mentors can blend it incorporates with traditional learning" (Al-Sharhan, 2016), and can ensure the face-to-face and easy access to online interaction (Ocak, 2010); "interactive in which it can provide an interactive learning environment” (Cavus \& Uzunboylu, 2009); "collaborative because it creates collaborative learning activities” (Uzunboylu et al., 2009); “immediate, it allows instant access to learning materials and educational instruction" (Eteokleous \& Ktoridou, 2009). Furthermore, Chen et al. (2013) find out that "mobile platforms allow learners to collaborate with their classmates, search information, find and search locations" (Chen et al., 2013)

Nowadays, mobile phones are cheaper than other devices like desktop computers or laptops, and hence, it is claimed that mobile is suitable for teaching and learning devices for the students at a low cost (Dawson, 2007; Haug \& Tumbo 2016). Many mobile operators have provided $4 \mathrm{G}$ services which made the m-learning popular and flexible for the students of the university. M-learning is the learning process through a mobile device (such as mobile/smartphones, iPods, MP3 players, personal digital assistant (PDAs) (Iqbal \& Bhatti, 2015) and helps to enhance knowledge and learning outside of the classroom and also helps to develop the student-teacher's relation (Ekamayake \& Wishart, 2010; Wishart, 2015).

Dashti and Aldashti (2015) also had conducted a study on "students' perceptions toward the use of mobile learning at the College of Basic Education in Kuwait" where they had distributed 300 questionnaires among the female students and found $80.3 \%$ were satisfied by using mobile devices as a learning tool and they claimed that mobile learning enhances their knowledge of English language (Dashti and Aldashti, 2015). Another study conducted by Nassuora (2013) to examine students' acceptance of mobile learning in Saudi Arabia. The author had found that m-learning acceptance of Saudi Arabia is high at the higher studies level by using questionnaires survey among 80 students (Nassuora, 2013). Another study of mobile phone usage and potential for $\mathrm{m}$ learning based on Panama by Valderrama Bahamóndez and Scmidt (2010) had found that mobile phone usages among school children are going high and teacher and students were all accept using their mobile phone for the purpose of learning. Chinese universities and colleges also used mobile as a 
learning and teaching tool that are supported by the government as well as university administration. By using mobile at the higher study level, students may access educational materials and get instructors instructions which help them distance learning and real-time access to learning databases (Xu et al., 2019). Mobile learning is considered as a part of e-learning as well as distance learning. By using mlearning, facilitators may motivate the students to learn from inside and outside the classroom (Hamdani, 2013). Usually, Mobile phone like a smartphone is the device that is used as widely for learning (Ken Nee Chee, Noraffandy Yahaya, Nor Hasniza Ibrahim, \& Mohamed Noor Hasan, 2017). A similar study on 'Students' Perceptions of Mobile Technology in Higher Education: Preparation to Design Mobile Learning Models" by (Pebriantika et al., 2019) found that students are familiar with mobile learning technology. By using a survey method of 100 students they had also found that the students have a positive perception of mobile technology at higher education in Indonesia. The literature also shows that the use of mobile phone devices is the most popular learning tool in higher education. Mobile learning is potentially the most exciting, innovative, and technologically advanced system that will help the effect of revolutionizing the delivery of the higher education institution in the future. It is regarded as a unique tool in various settings of the educational institution (Ahmad, 2015, 2018, 2019a, 2019b). On the other side, University students are considered as heavy users of mobile phone and it helps to improve the learning outcome at the tertiary level. By using a mobile phone with internet connection student acquire knowledge which helps them to enrich their knowledge while they attend their lectures (Ahmad, 2020)

In the context of Bangladesh, Ahmed and Kabir (2018) An empirical research on smartphone acceptance of undergraduate students especially business studies students as a learning tool of private university perspective in Bangladesh where they use UTAUT2 model. The result found that there has a high degree of acceptance of smartphones as a learning tool in the context of Bangladesh. Hossain and Ahmed (2016) researched on "Academic use of smartphones by university students: a developing country perspective" Out of 316 respondents of the university students found that almost two-thirds of the respondents used their mobile phones to access academic information. They also found one-thirds of the students do not use their mobile phone for learning though around $90 \%$ of respondents of this study were interested in downloading various apps for their academic learning. Hossain (2014) found $68.67 \%$ of students use smartphones based on the research on university students in Bangladesh for the purpose of social media, entertainment, sports information and listening to music. However, only $23.7 \%$ used their smartphone for academic purposes. Therefore, there has a perspective on the perception of students of using mobile for learning at this COVID-19 pandemic time at the tertiary level in Bangladesh.

\section{METHODOLOGY}

The research is conducted of quantitative descriptive with survey methods. The Participants of this research were students from the various universities in Bangladesh. Irrespective of gender all the students of the university-level were eligible to take part in this survey. The developed questionnaire based on the previous literature. The structure of the questionnaires was modified from several former studies (Ahmed, 2020; Al-Fahad, 2009; Al-Hunaiyyan et al., 2016; Dashti \& Aldashti, 2015; Nassuora, 2013). The questionnaire consisted of three parts. Part 1 collects basic information of students and gathers information about the operating system of students' cell phones, frequency of using the internet, time spending on mobile phones every day, and use mobile phones for academic purposes or not. Part 2 investigates the preference of social networking sites for learning and frequent use of the common social media applications. Part 3 of the questionnaire measures students' perceptions and attitudes towards the effectiveness of mobile learning and social media learning tools during COVID-19 pandemic time. The questions in Part 3 consisted of 5-point Likert Scale ranging from 'Strongly Disagree' (1) to 'Strongly Agree' (5). Before finalizing the questionnaire minor changes were made based on a pilot survey conducted on some students to assess the feasibility of the survey. Unlike some previous research that emphasis only on students' perceptions, this study explores students' perceptions of mobile learning during this pandemic time. This study also focuses on the uses of social media in higher education through mobile learning in Bangladesh.

\section{RESULTS AND FINDINGS}

The questionnaire shared by the google doc was randomly distributed among undergraduate and postgraduate level students of several universities of Bangladesh through various social networking sites where a significant number of students took part in this online survey. Out of them a total of 416 responses were found valid and considered for data analysis. By using SPSS software, the collected data were analyzed quantitatively. This section presents results of the study including basic information of respondents as well as university students, the operating system of university students' cell phone, frequency of using the internet, time spending on mobile phone every day, use mobile phone for academic purpose or not, preference of social networking sites for learning, university students' frequent use of social media applications, and university students' perception and attitude about mobile learning.

\section{Background Information of Respondents}

This section represents some basic information of the university students (416 responses). Table 1 shows the outputs of the questions related to gender, age and level of education. 
Table 1. Basic Information of Students $(\mathrm{N}=416)$

\begin{tabular}{ccc}
\hline & \multicolumn{2}{c}{ Percentage (\%) } \\
\hline \multirow{2}{*}{ Gender } & Male & 64.4 \\
\cline { 2 - 3 } & Female & 35.6 \\
\cline { 2 - 3 } Age & $16-20$ Years & 65.4 \\
\cline { 2 - 3 } & 21-25 Years & 33.7 \\
\cline { 2 - 3 } & 26-30 Years & 1.0 \\
\hline \multirow{2}{*}{ Level of Education } & Undergraduate & 97.6 \\
\cline { 2 - 3 } & Postgraduate & 2.4 \\
\hline
\end{tabular}

In addition, Figures 1-4 illustrate the operating system of university students' cell phones, frequency of using internet by university students, time spending by university students on mobile phone every day and use of mobile phone by university students for academic purposes or not respectively.

\section{University Students' Use of Social Media Applications}

This section of the questionnaire examines university students' preference to social networking sites for learning, as shown by Figure 5 and to what extent university students' use some selected social media applications such as Facebook,

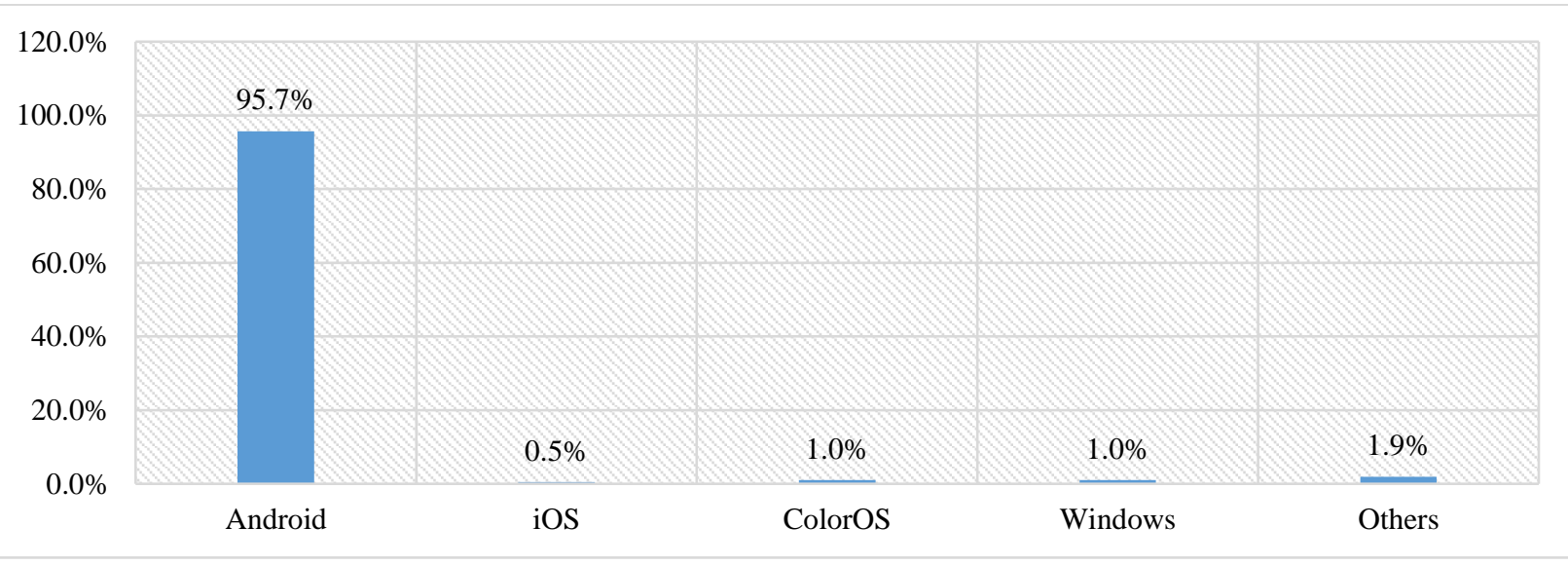

Figure 1. Operating System of University Students' Cell Phone

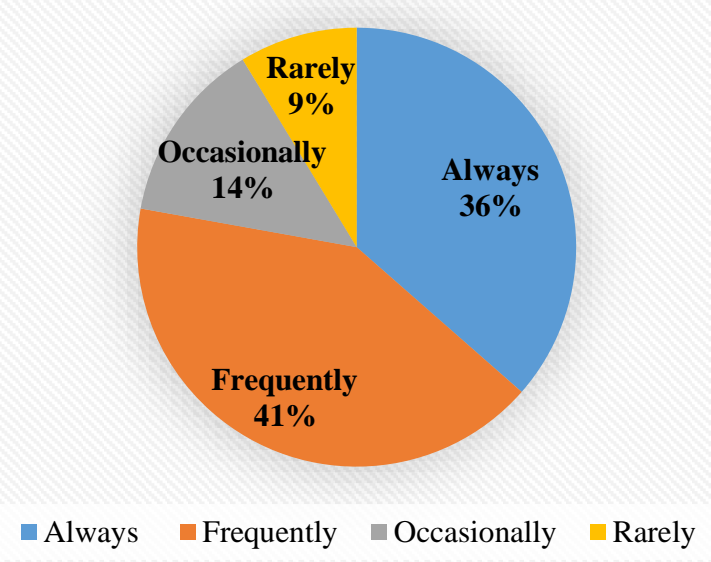

Figure 2. Frequency of Using Internet

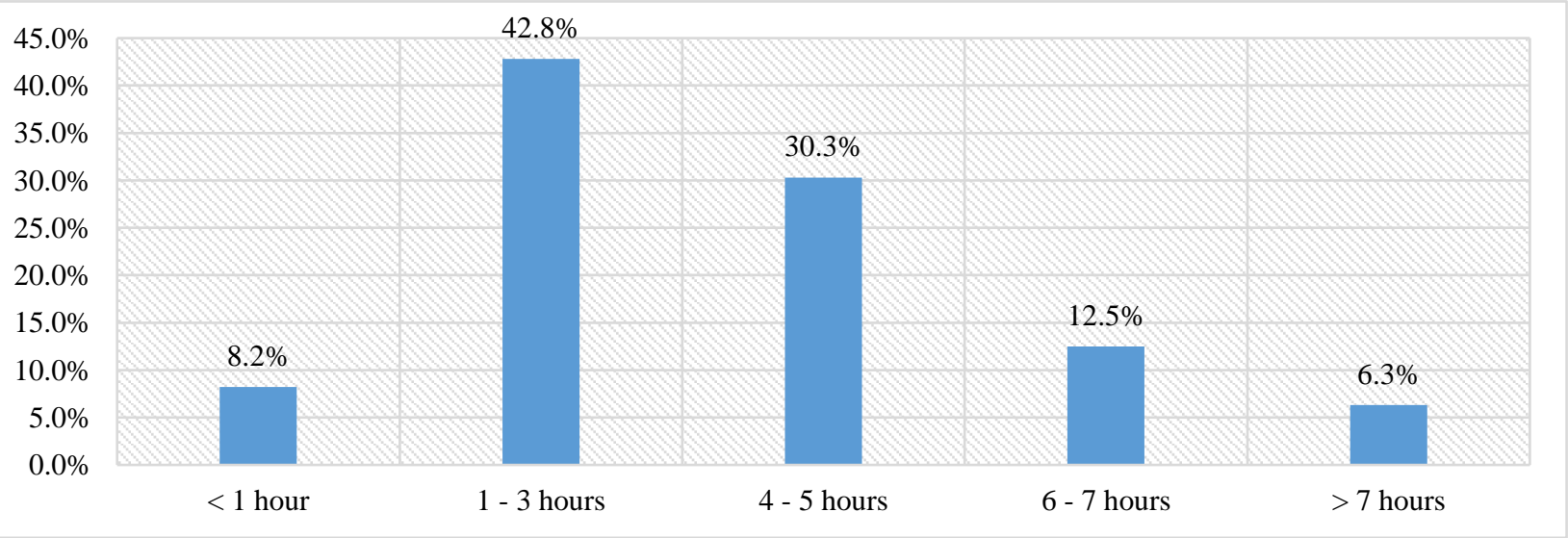

Figure 3. Time Spending on Mobile Phone Every Day 


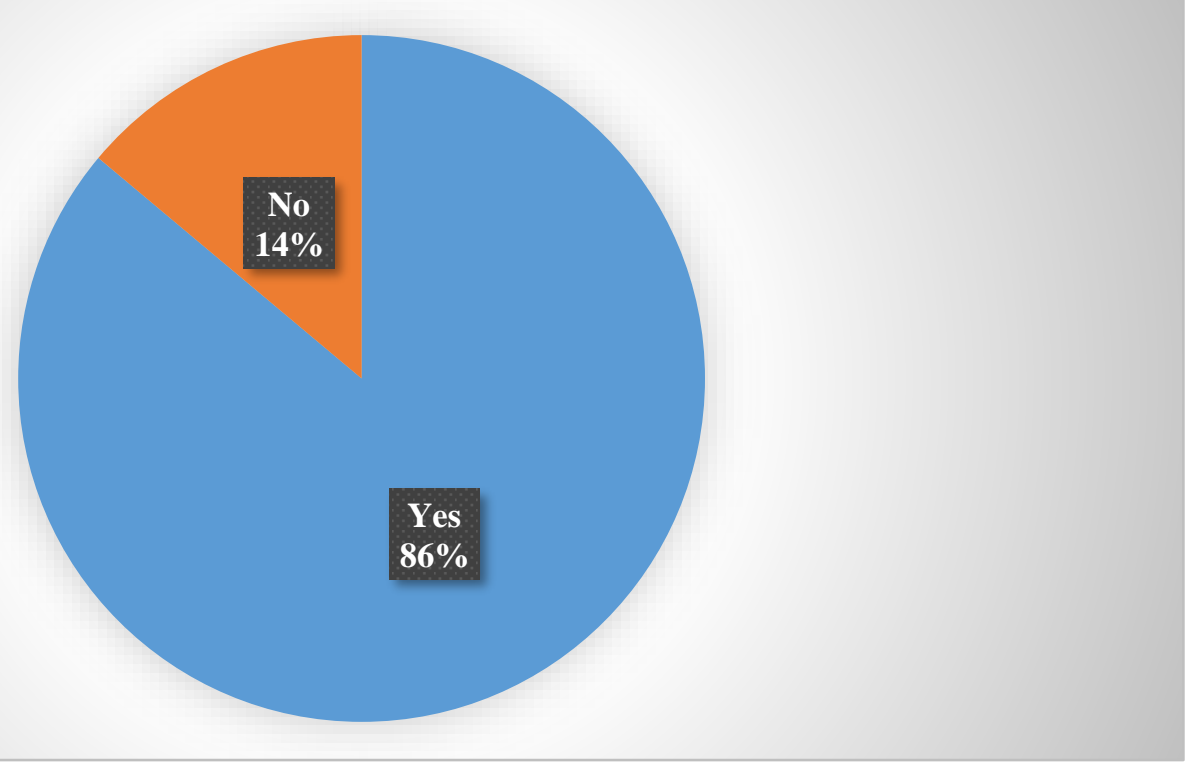

Figure 4. Use Mobile Phone for Academic Purpose or Not

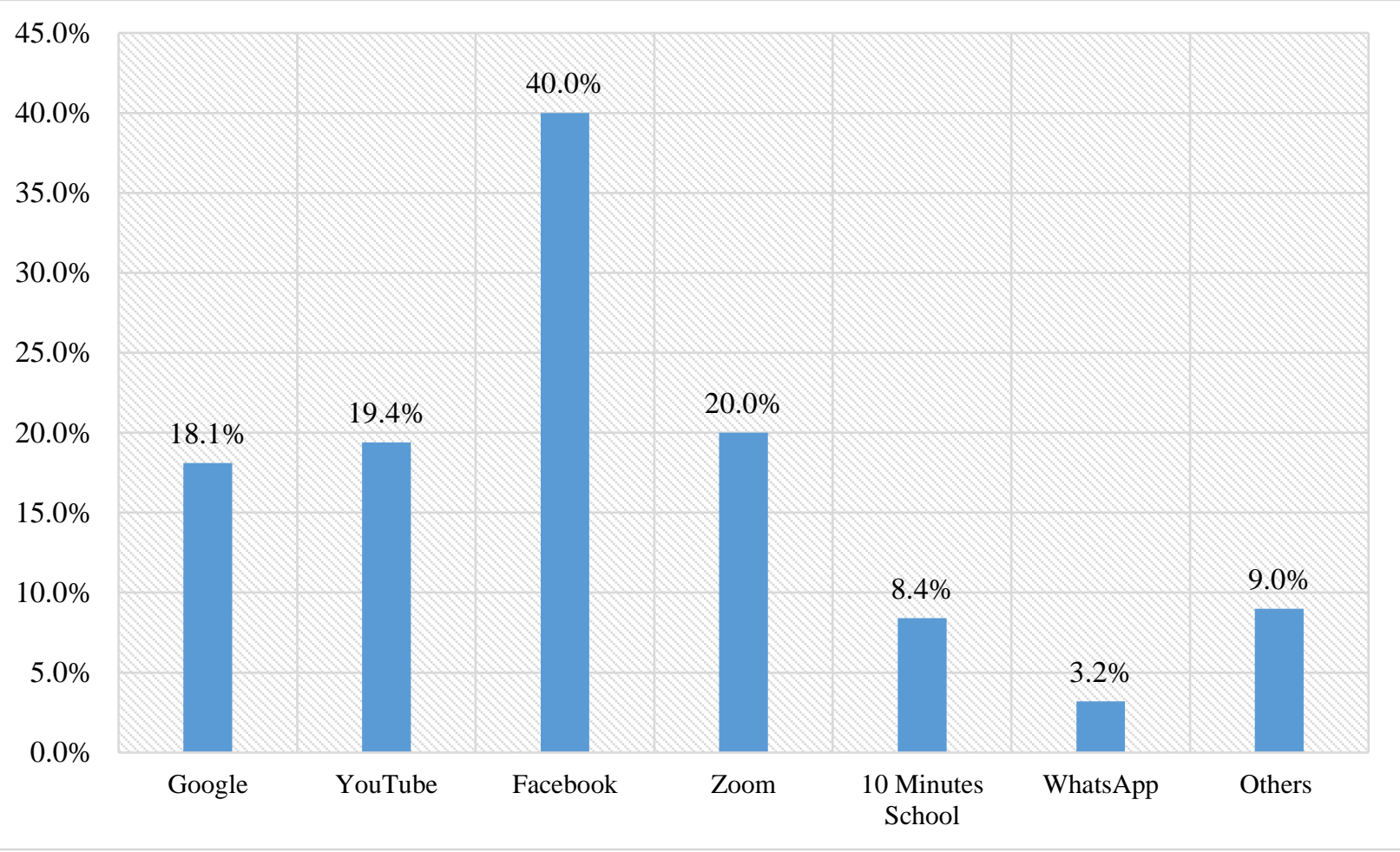

Figure 5. Preference of Social Networking Sites for Learning (Multiple Response)

Table 2. University Students' Use of Social Media Applications

\begin{tabular}{ccccc}
\hline Application & Always & Frequently & Occasionally & I don't use it \\
\hline 1. Facebook & $36.1 \%$ & $44.7 \%$ & $18.3 \%$ & $1.0 \%$ \\
\hline 2. Twitter & $0.5 \%$ & $6.3 \%$ & $7.2 \%$ & $86.0 \%$ \\
\hline 3. Instagram & $5.3 \%$ & $13.0 \%$ & $13.9 \%$ & $67.8 \%$ \\
\hline 4. LinkedIn & $1.9 \%$ & $4.3 \%$ & $6.3 \%$ & $87.5 \%$ \\
\hline 5. YouTube & $24.5 \%$ & $45.2 \%$ & $25.0 \%$ & $5.3 \%$ \\
\hline 6. WhatsApp & $13.5 \%$ & $27.5 \%$ & $27.4 \%$ & $31.7 \%$ \\
\hline 7. Google+ & $20.2 \%$ & $31.8 \%$ & $20.2 \%$ & $27.9 \%$ \\
\hline
\end{tabular}

Twitter, Instagram, LinkedIn, YouTube, WhatsApp and Google+, which are shown in Table 2.

\section{University Students' Perception of Mobile Learning}

This section of the questionnaire measures university students' perceptions and attitudes about mobile learning during COVID-19 pandemic time. Table 3 represents the results of this section. Percentage is used to figure out the real picture of this segment especially perception based questions (5 strongly agree to 1 strongly disagree). Moreover, the mean represents the general average of university students' responses, while standard deviation indicates the difference of university students' responses to a question vary or deviate from the mean. The value of standard deviation is around 1 , as 
Table 3. University Students' Perception on Mobile learning

\begin{tabular}{|c|c|c|c|c|c|c|c|}
\hline Question & $\begin{array}{c}\text { Strongly } \\
\text { Agree }\end{array}$ & Agree & Neutral & Disagree & $\begin{array}{l}\text { Strongly } \\
\text { Disagree }\end{array}$ & Mean & $\begin{array}{r}\text { Standard } \\
\text { Deviation }\end{array}$ \\
\hline Q1. The use of mobile is flexible to learn anytime, anywhere & $17.3 \%$ & $51.9 \%$ & $17.3 \%$ & $9.1 \%$ & $4.3 \%$ & 3.69 & 1.004 \\
\hline $\begin{array}{l}\text { Q2. Mobile learning is a good idea to minimize the study gap during } \\
\text { covid-19 pandemic time }\end{array}$ & $18.3 \%$ & $56.2 \%$ & $15.9 \%$ & $6.7 \%$ & $2.9 \%$ & 3.80 & .918 \\
\hline Q3. Mobile is easier to find relevant information of my studies & $17.3 \%$ & $64.0 \%$ & $10.6 \%$ & $6.3 \%$ & $1.9 \%$ & 3.88 & .818 \\
\hline Q4. Mobile learning helps to improve my study skills & $15.9 \%$ & $63.9 \%$ & $9.6 \%$ & $6.7 \%$ & $3.8 \%$ & 3.81 & .916 \\
\hline Q5. Mobile is easier to access to find my study materials & $15.4 \%$ & 5 & $16.8 \%$ & & $8 \%$ & & .956 \\
\hline $\begin{array}{l}\text { Q6. Mobile is easier to share in class-related discussions both online and } \\
\text { offline during covid-19 period }\end{array}$ & $18.3 \%$ & $54.8 \%$ & $15.4 \%$ & $8.2 \%$ & $3.4 \%$ & 3.76 & .957 \\
\hline Q7. The use of mobile helps to improve knowledge in my field of study & $14.9 \%$ & $66.9 \%$ & $82 \%$ & $67 \%$ & $3.4 \%$ & 3.83 & .882 \\
\hline $\begin{array}{l}\text { Q8. Mobile learning helps to enhance my motivation to finish my studies } \\
\text { during this pandemic time }\end{array}$ & $10.1 \%$ & $56.8 \%$ & $20.2 \%$ & $11.1 \%$ & $1.9 \%$ & 3.64 & .864 \\
\hline Q9. Mobile helps me to solve study related problem & $15.9 \%$ & $67.3 \%$ & $9.1 \%$ & $4.8 \%$ & $2.9 \%$ & 3.88 & .832 \\
\hline $\begin{array}{l}\text { Q10. Mobile learning helps me to learn different ways and provide } \\
\text { various learning fields }\end{array}$ & $15.9 \%$ & $64.0 \%$ & $12.5 \%$ & $5.8 \%$ & $1.9 \%$ & 3.86 & .815 \\
\hline $\begin{array}{l}\text { Q11. The use of social media applications helps in educational } \\
\text { fulfillment during covid-19 period }\end{array}$ & $13.0 \%$ & $60.1 \%$ & $16.3 \%$ & $9.1 \%$ & $1.4 \%$ & 3.74 & .851 \\
\hline $\begin{array}{l}\text { Q12. The use of social media helps to strengthen the communication } \\
\text { with others }\end{array}$ & $18.3 \%$ & $70.6 \%$ & $8.2 \%$ & $1.9 \%$ & $1.0 \%$ & 4.03 & .655 \\
\hline Q13. Mobile learning is a faster way to get feedback & 11 & 34. & 0.1 & & 2.31 & 3.53 & o \\
\hline $\begin{array}{l}\text { Q14. Mobile learning helps to improve interactivity between student and } \\
\text { teacher }\end{array}$ & $13.5 \%$ & $60.6 \%$ & 15.4 & 7.7 & $2.9 \%$ & 3.74 & .890 \\
\hline Q15. During covid-19 time, mobile acts as a learning companion & $12.0 \%$ & $66.3 \%$ & $13.9 \%$ & $5.8 \%$ & $1.9 \%$ & 3.81 & .793 \\
\hline $\begin{array}{l}\text { Q16. At this pandemic time, high internet charge of mobile network can } \\
\text { affect my learning }\end{array}$ & $46.6 \%$ & $41.3 \%$ & 720 & $29 \%$ & $1.9 \%$ & 4.28 & .868 \\
\hline $\begin{array}{l}\text { Q17. I think mobile learning will help me to recover my study gap at this } \\
\text { pandemic time }\end{array}$ & $17.3 \%$ & $59.6 \%$ & $13.0 \%$ & $7.7 \%$ & $2.4 \%$ & 3.89 & .893 \\
\hline Q18. Screen size of my mobile does not affect my learning & $8.2 \%$ & $51.4 \%$ & $16.3 \%$ & $15.4 \%$ & $8.7 \%$ & 3.35 & 1.106 \\
\hline
\end{tabular}

shown in Table 3 by which it is clear that the response of each question is close to the average.

\section{DISCUSSIONS}

Nowadays mobile phone has been playing an important role in students' everyday life especially for their educational purpose (Rahman, 2014). Availability of mobile phone among students are also paving the way for shifting focus to mobile learning to continue their study (AlHajri, Al-Sharhan, \& AlHunaiyyan, 2017) especially in an unexpected situation such as COVID-19 pandemic. Table 1 shows respondents as well as university students' background information, in which $64.4 \%$ are male and $35.6 \%$ are female, $65.4 \%$ are aged $16-20$ years whether $33.7 \%$ belong to $21-25$ years and remaining $1.0 \%$ comes from 26-30 years age group, and almost all the respondents (97.6\%) are currently studying at the undergraduate level and the remaining (2.4\%) belong to postgraduate level. Figure 1 reveals that more than 95 percent (95.7\%) cell phones of university students are being operated by android operating system and the remaining consist of iOS (0.5\%), colorOs (1.0\%), windows (1.0\%) and others (1.9\%). Figure 2 displays the frequency of using internet by university students in which more than one-third (36.5\%) always use the internet, $41.4 \%$ use the internet frequently, $13.5 \%$ occasional users and $8.7 \%$ use the internet rarely. Figure 3 illustrates time spending scenario on the mobile phone by university students in a day in which $42.8 \%$ spend $1-3$ hours on mobile phone in a day, $30.3 \%$ spend $4-5$ hours, $12.5 \%$ spend $6-7$ hours, $8.2 \%$ spend less than one hour and $6.3 \%$ spend more than seven hours on mobile phone in a day. But, it is a matter of fact that, despite having access to mobile phone as well as internet $13.9 \%$ respondents cum university students do not use mobile phone for their academic purpose, as shown by Figure 4 that indicates reservation prevails among some students in terms of using mobile phone for educational purpose.

In recent times, mobile devices are getting more preference in terms of getting easy access to different social networking sites and using various social media applications. For that reason, students including university level are utilizing these opportunities of mobile devices through collaboration, engagement and interactivity among them that help themselves to easily share any type of academic documents or reading materials by using these social media platforms (AlHajri, Al-Sharhan, \& Al-Hunaiyyan, 2017). Figure 5 displays that $40.0 \%$ of university students show preference on Facebook for learning, 18.1\% on Google, 19.4\% on YouTube, $20.0 \%$ on Zoom and so on. Various studies identified that there is an increasing demand for academic apps among the students for its learning support (Hossain and Ahmed, 2016). Social media applications are also playing a crucial role in this case. Table 2 also shows the frequency of use of social media applications by university students. It is interesting to mention that in the context of Bangladesh $80.8 \%$ university students are frequent user of Facebook, followed by YouTube (69.7\%) and Google+ (52.0\%), while mild interest in WhatsApp (41.0\%) and did not show much interest in Instagram, Twitter and LinkedIn. So, policy-makers of the education sector of Bangladesh should focus on students' preferential social media applications such as Facebook, YouTube and Google+ while initiating any policy related to mobile learning. 
Table 3 reveals that university students' have shown positive attitudes about mobile learning. In response to perception-based questions, more than two-thirds of students (69.2\%) think that mobile gives them the flexibility to learn anytime and anywhere. $74.5 \%$ university students seem that mobile learning is a good idea to minimize the study gap during COVID-19 pandemic time, while $78.3 \%$ believe that mobile can act as a learning companion in any situation and be very relevant in any unexpected situation like COVID-19 pandemic period. $81.3 \%$ university students mention that mobile is easier to find relevant information, while $71.2 \%$ state that it is easier for them to find out study materials through mobile phone and $73.1 \%$ mention that they can easily share class-related documents and discussions both online and offline by using their mobile during COVID-19 period. Mobile learning helps students in many ways such as $79.8 \%$ university students mention the assistance of mobile learning to improve their study skills, $81.8 \%$ express that it is possible to improve knowledge in their field of study by mobile learning, $83.2 \%$ have faith that mobile learning can easily solve study-related problems and $79.9 \%$ have trust that mobile learning helps them to learn different ways and provide various learning fields, while $66.9 \%$ agree that mobile learning helps to enhance their motivation to finish their studies during this pandemic time. Besides $74.1 \%$ university students have belief that mobile learning helps to improve the interactivity between student and teacher and $63.9 \%$ focus that mobile learning is a faster way to get feedback such as students can get a response at any time, be it office hour or not, from their teachers by using mobile devices, while $88.9 \%$ think that the use of social media helps to strengthen the communication with others. Interestingly, $59.6 \%$ of university students seem that the screen size of their mobile does not affect their learning. Furthermore, $73.1 \%$ of university students feel that the use of social media applications helps in educational fulfillment during COVID-19 period. Despite having enthusiasm for mobile learning, $87.9 \%$ of university students argue that mobile learning can be negatively affected by high internet charge of mobile networks at this pandemic time which is a matter of serious concern.

Based on the outputs of this study and findings of related existing studies conducted by AlHajri, Al-Sharhan, and AlHunaiyyan (2017), Hossain and Ahmed (2016), Rahman (2014) etc., it can be said mobile learning is a very useful mechanism to ensure normal studying of the students of all level particularly university level in all weather, be it normal condition or unpredicted situation like COVID-19 pandemic, if the necessary arrangements such as logistics, availability of internet, etc. be already in place.

\section{CONCLUSION}

The education sector of Bangladesh has been taken various initiatives to utilize Information and Communications Technologies (ICT) at every stage of education from primary to tertiary levels. The main focus of this study is to measures the student's perception of using mobile for learning during COVID-19 in Bangladesh especially at the university student's perspective. The study shows that students are very familiar with mobile learning, have a positive perception of mobile learning, and students used various social media for their study during COVID-19 pandemic time. The findings also demonstrate that mobile learning is a useful tool for this pandemic time where students can learn from outside of the classroom or participate in class from anywhere; improve the relationship with their teacher and also fulfill the long term study gap. The policymaker as well as the educational institutions should consider the opportunity to incorporate mobile learning technology for the whole education system where social media may enhance the process of teaching and learning. In addition, university-level students have positive opinions about mobile learning and willingness to be part of which is very crucial for the institutionalization of mobile learning in the universities in Bangladesh.

\section{REFERENCES}

Ahmad, T. (2015). Preparing for the future of higher education. On the Horizon, 23(4), 323-330. https://doi.org/10.1108/OTH-06-2015-0029

Ahmad, T. (2018). Teaching evaluation and student response rate. PSU Research Review, 2(3), 206-211. https://doi.org/10.1108/PRR-03-2018-0008

Ahmad, T. (2019a). Undergraduate mobile phone use in the Caribbean: Implications for teaching and learning in an academic setting. Journal of Research in Innovative Teaching and Learning. https://doi.org/10.1108/JRIT-01-2019-0001

Ahmad, T. (2019b). Mobile phone messaging to increase communication and collaboration within the university community. Library Hi Tech News, 36(8), 7-11. https://doi.org/10.1108/LHTN-08-2019-0054

Ahmad, T. (2020). Student perceptions on using cell phones as learning tools: Implications for mobile technology usage in Caribbean higher education institutions. PSU Research Review, 4(1), 25-43. https://doi.org/10.1108/PRR-03-20180007

Ahmed, M. S., \& Kabir, A. (2018). The Acceptance of Smartphone as a Mobile Learning Tool: Students of Business Studies in Bangladesh. Malaysian Online Journal of Educational Technology, 6(2), 38-47. https://doi.org/10.17220/mojet.2018.02.003

Al Hamdani, D. S. (2013). Mobile learning: A good practice. Procedia-Social and Behavioral Sciences, 103, 665-674. https://doi.org/10.1016/j.sbspro.2013.10.386

Al-Emran, M., Elsherif, H. M., \& Shaalan, K. (2016). Investigating attitudes towards the use of mobile learning in higher education. Computers in Human behavior, 56, 93102. https://doi.org/10.1016/j.chb.2015.11.033

Al-Fahad, F. N. (2009). Students' attitudes and perceptions towards the effectiveness of mobile learning in King Saud University, Saudi Arabia. Online Submission, 8(2), 111-119.

AlHajri, R., Al-Sharhan, S., \& Al-Hunaiyyan, A. (2017). Students' perceptions of mobile learning: case study of Kuwait. International Scholarly and Scientific Research \& Innovation, 11(2), 371-374. 
Al-Hunaiyyan, A., Alhajri, R. A., \& Al-Sharhan, S. (2018). Perceptions and challenges of mobile learning in Kuwait. Journal of King Saud University-Computer and Information Sciences, 30(2), 279-289. https://doi.org/10.1016/ j.jksuci.2016.12.001

Al-Hunaiyyan, A., Al-Sharhan, S., \& Alhajri, R. (2017). A new mobile learning model in the context of the smart classrooms environment: a holistic approach. International Journal of Interactive Mobile Technologies (iJIM), 11(3), 3956. https://doi.org/10.3991/ijim.v11i3.6186

Al-Sharhan, S. (2016). Smart classrooms in the context of technology-enhanced learning (TEL) environments. In M. Ally \& K. Alshahrani (Eds.), Transforming Education in the Gulf Region: Emerging Learning Technologies and Innovative Pedagogy for the 21st Century. Taylor \& Francis. https://doi.org/10.4324/9781315621586

Burden, K., \& Kearney, M. (2016). Future scenarios for mobile science learning. Research in Science Education, 46(2), 287308. https://doi.org/10.1007/s11165-016-9514-1

Cavus, N., \& Ibrahim, D. (2009). m-Learning: An experiment in using SMS to support learning new English language words. British journal of educational technology, 40(1), 7891. https://doi.org/10.1111/j.1467-8535.2007.00801.x

Cavus, N., \& Uzunboylu, H. (2009). Improving critical thinking skills in mobile learning. Procedia-Social and Behavioral Sciences, 1(1), 434-438. https://doi.org/10.1016/ j.sbspro.2009.01.078

Chandan, Md. S.K. (2015, March 28). A New Bangladesh. The Daily Star. Retrieved from http://www.thedailystar.net/anew-bangladesh-17482

Chee, K. N., Yahaya, N., Ibrahim, N. H., \& Hasan, M. N. (2017) Review of mobile learning trends 2010-2015: A metaanalysis. Journal of Educational Technology \& Society, 20(2), 113-126.

Chen, B., Sivo, S., Seilhamer, R., Sugar, A., \& Mao, J. (2013). User acceptance of mobile technology: A campus-wide implementation of blackboard's mobile ${ }^{\mathrm{TM}}$ learn application. Journal of educational computing research, 49(3), 327-343. https://doi.org/10.2190/EC.49.3.c

Dashti, F., \& Aldashti, A. (2015). EFL College Students' Attitudes towards Mobile Learning. International Education Studies, 8(8), 13-20. https://doi.org/10.5539/ies.v8n8p13

Dawson, D. (2007). Handheld technology for mobile learning. London: Latimer Trend.

Ekanayake, T. M. S. S. K. Y., \& Wishart, J. (2011). Investigating the possibility of using mobile phones for science teaching and learning: Is it a viable option for Sri Lanka. International Journal for Cross-Disciplinary Subjects in Education (IJCDSE), 2(2), 372-380. https://doi.org/10.20533/ijcdse.2042.6364.2011.0052

Eteokleous, N., \& Ktoridou, D. (2009). Investigating mobile devices integration in higher education in Cyprus: Faculty perspectives. International Journal of Interactive Mobile Technologies, 3(1), 38-48. https://doi.org/10.3991/ ijim.v3i1.762
Fuegen, S. H. (2012). The impact of mobile technologies on distance education. TechTrends, 56, 49-53. https://doi.org/10.1007/s11528-012-0614-0

Habib, A., \& Hoque, A. L. (2010, December). Towards mobile based e-learning in Bangladesh: A framework. In 2010 13th International Conference on Computer and Information Technology (ICCIT) (pp. 300-305). IEEE.

Hashemi, M., Azizinezhad, M., Najafi, V., \& Nesari, A. J. (2011). What is mobile learning? Challenges and capabilities. Procedia-Social and Behavioral Sciences, 30, 2477-2481. https://doi.org/10.1016/j.sbspro.2011.10.483

Haug, R., \& Tumbo, S. (2016). Mobile learning bridging the gap in agricultural extension service delivery: Experiences from Sokoine University of Agriculture, Tanzania, Camilius Sanga and Malongo Mlozi Sokoine University of Agriculture, Tanzania. International Journal of Education and Development using Information and Communication Technology, 12(3), 108-127.

Hossain, M. (2015). The use of smartphone in accessing information: A case of Dhaka university students (Doctoral dissertation), University of Dhaka.

Hossain, M. E., \& Ahmed, S. M. Z. (2016). Academic use of smartphones by university students: a developing country perspective. The Electronic Library, 34(4), 651-665. https://doi.org/10.1108/EL-07-2015-0112

Iqbal, S., \& Ahmed Bhatti, Z. (2015). An investigation of university student readiness towards m-learning using technology acceptance model. International Review of Research in Open and Distributed Learning, 16(4), 83-103. https://doi.org/10.19173/irrodl.v16i4.2351

Kinash, S., Brand, J., \& Mathew, T. (2012). Challenging mobile learning discourse through research: Student perceptions of Blackboard Mobile Learn and iPads. Australasian journal of educational technology, 28(4), 639-655. https://doi.org/10.14742/ajet.832

Klassen, A., Eibrink-Lunzenauer, M., \& Gloggler, T. (2013). Requirements for mobile learning applications in higher education. Published in Multimedia (ISM), 2013 IEEE International Symposium, 492-497. https://doi.org/10.1109/ ISM.2013.94

Kukulska-Hulme, A. (2009). Will mobile learning change language learning?. ReCALL, 21(2), 157-165. https://doi.org/10.1017/S0958344009000202

Mobile Phone Subscribers Bangladesh March 2019. Retrieved on 5 June 2020 from http://www.btrc.gov.bd/content/ mobile-phone-subscribers-bangladesh-march-2019

Naciri, A., Baba, M. A., Achbani, A., \& Kharbach, A. (2020). Mobile learning in Higher education: Unavoidable alternative during COVID-19. Aquademia, 4(1), ep20016. https://doi.org/10.29333/aquademia/8227

Nassuora, A. B. (2012). Students acceptance of mobile learning for higher education in Saudi Arabia. American Academic \& Scholarly Research Journal, 4(2), 24-30.

Ocak, M. A. (2011). Blend or not to blend: a study investigating faculty members perceptions of blended teaching. World Journal on Educational Technology, 2(3), 196-205. 
Ozdamli, F., \& Cavus, N. (2011). Basic elements and characteristics of mobile learning. Procedia-Social and Behavioral Sciences, 28, 937-942. https://doi.org/10.1016/ j.sbspro.2011.11.173

Pebriantika, L. (2019). Needs analysis for the development of e-modules as teaching materials. Asia Proceedings of Social Sciences, 4(3), 49-51. https://doi.org/10.31580/ apss.v4i3.843

Quinn, C. (2000). M-Learning: Mobile, Wireless, In-YourPocket Learning. LiNE Zine 2006.

Rahman, M. A. (2014). The awareness and usage of mobile phone among students of Dhaka University of Bangladesh. Journal of Business Studies, 35(3), 17-30.

Rosenberg, M. J., \& Foshay, R. (2002). E-learning: Strategies for delivering knowledge in the digital age. Performance Improvement, 41(5), 50-51. https://doi.org/10.1002/ pfi.4140410512

Sharples, M. (2005). Learning as conversation transforming education in the mobile age (pp. 147-152).

Sönmez, A., Göçmez, L., Uygun, D., \& Ataizi, M. (2018). A review of current studies of mobile learning. Journal of Educational Technology \& Online Learning, 1(1), 12-27. https://doi.org/10.31681/jetol.378241

Toquero, C. M. (2020). Challenges and opportunities for higher education amid the COVID-19 pandemic: The Philippine context. Pedagogical Research, 5(4), em0063. https://doi.org/10.29333/pr/7947

Usak, M., Masalimova, A. R., Cherdymova, E. I., \& Shaidullina, A. R. (2020). New playmaker in science education: COVID19. Journal of Baltic Science Education, 19(2), 180-185. https://doi.org/10.33225/jbse/20.19.180
Uzunboylu, H., Cavus, N., \& Ercag, E. (2009). Using mobile learning to increase environmental awareness. Computers \& Education, 52(2), 381-389. https://doi.org/10.1016/ j.compedu.2008.09.008

Valderrama Bahamóndez, E. D. C., \& Schmidt, A. (2010). A survey to assess the potential of mobile phones as a learning platform for panama. In CHI'10 Extended Abstracts on Human Factors in Computing Systems (pp. 3667-3672). https://doi.org/10.1145/1753846.1754036

Winters, N., 2006. What is mobile learning? In: M. Sharples (Ed.), Big Issues in Mobile Learning. Kaleidoscope Network of Excellence, Mobile Learning Initiative, Nottingham, pp. 5-9.

Wishart, J. (2015, October). Assimilate or accommodate? The need to rethink current use of the term 'mobile learning'. In International Conference on Mobile and Contextual Learning (pp. 229-238). Springer, Cham. https://doi.org/10.1007/978-3-319-25684-9_17

World Health Organization. (2020b). Statement on the meeting of the International Health Regulations (2005) Emergency Committee regarding the outbreak of novel coronavirus (2019$n \mathrm{CoV})$. Retrieved on 25 April 2020 from https://bit.ly/2RwodiW

Xu, X., Li, D., Sun, M., Yang, S., Yu, S., Manogaran, G., Mastorakis, G., \& Mavromoustakis, C. X. (2019). Research on key technologies of smart campus teaching platform based on 5G network. IEEE Access, 7, 20664-20675. https://doi.org/10.1109/ACCESS.2019.2894129 